Article

\title{
Social Determinants of Success: Social Media, Corporate Governance and Revenue
}

\author{
Jordi Paniagua ${ }^{1}$, Rafael Rivelles ${ }^{2}$ and Juan Sapena ${ }^{2, *(1)}$ \\ 1 Department of Applied Economics II, University of Valencia, Av. Tarongers s/n, 46022 Valencia, Spain; \\ jordi.paniagua@uv.es \\ 2 Faculty of Economics and Business Administration, Catholic University of Valencia, Calle Corona 34, \\ 46003 Valencia, Spain; iam@rafarivelles.com \\ * Correspondence: juan.sapena@ucv.es
}

Received: 29 June 2019; Accepted: 11 September 2019; Published: 20 September 2019

\begin{abstract}
This study examined how social media (Twitter and LinkedIn) relates to the operating revenue by investigating the effect of the use of social media by the board of directors. To tackle this question, we analyzed the mediating and moderating relationship of social media on the effect of board size in operating revenue (turnover). We studied the implications of the use of social media by the board members by using structural equation modeling (SEM). The data consisted of a random sample of 100 companies listed on the NASDAQ. The study makes two main contributions. First, it shows interesting differences in the use of social media for the operating revenue. Our results suggest that while Twitter mediated and inhibited the negative effect of board size on revenue, LinkedIn moderated and re-enforced this effect. Second, it offers marketers and managers some useful hints about the relationship between social media and financial performance.
\end{abstract}

Keywords: social media; Twitter; turnover; corporate government; board of directors; board members

\section{Introduction}

This study explores the social determinants of financial performance through two approaches: the use of social media by the company and by the board of directors. The use of social media-in this study, Twitter and LinkedIn - was analyzed as a mediating and moderating factor affecting the relationship between board size and operating revenue. This novel study used structural equation modeling (SEM) to test for mediating and moderating effects (100 companies listed on the NASDAQ in 2015). The study had three salient features. First, it showed how social media relates to operating revenue via corporate governance. Second, a salient feature of the study was to test the hypotheses with two different social media platforms. In particular, it showed whether the use by the board of directors of professional networking platforms (e.g., LinkedIn) or general-purpose networking (Twitter) yielded the best returns for the company. Third, it offers marketers and managers some useful hints about the relationship between social media and financial performance. The academic debate on the link between social media and financial performance has not reached a consensus. Does the use of social media by the board of directors have any financial implications for their companies? If so, what is the best social media platform for company executives?

According to Felix et al. [1], social media dimensions include culture, scope, structure, and governance. They defined social media marketing governance as the way in which "the company establishes rules and guidelines and how social media marketing responsibilities are controlled in the company" (p. 120). In their study, they discovered that the paradox of social media marketing governance, in which the number of employees with authority to execute social media communication, was inversely related to the number of senior management guidelines. The aim of this paper is to go 
one step further to analyze whether the embeddedness of social media in corporate governance affects financial performance.

The conceptual framework and hypotheses are based on social capital theory and agency theory. On one hand, social capital and social media are prime targets of academic research because multiple empirical research streams have confirmed the importance of social capital and social networks as conduits for information and knowledge [2]. On the other hand, using agency theory, scholars have extensively analyzed the implications of board size for financial performance [3-9]. However, the relationship between board composition, social media, and firm financial performance is unclear. This study aims to fill this gap.

The direction (positive or negative) of the link between corporate governance, social media, and financial outcomes also remains uncertain in the literature. Some scholars have shown the dark side of social media, for example, certain studies have suggested that social networking can be a distraction [10]. Orlitzky et al. [11] found multiple contradictory linkages between social capital and firm performance. Moreover, the empirical findings in this area are still inconclusive.

The rest of the study is structured as follows. Section 2 develops the research hypotheses. Section 3 introduces the dataset and empirical method. Section 4 presents and discusses the results. Finally, Section 5 concludes with the research limitations, managerial implications, and avenues for future research.

\section{Conceptual Framework}

\subsection{Literature Review}

Notable research topics on social media and social capital include the following: the reasons for using the Internet and participating in online social networking sites [12]; linkages between social capital and opportunities in foreign markets and exports [13-15]; the way that social networks can provide tacit knowledge about international business practices [16-18]; the linkages between social media and business performance [9,19-22]; the way that social networks can help address financial crises [23]; the use of social media to predict stock movements in financial markets [24-26]; employee creativity; and even the ability of social networks to help predict real world outcomes [27].

Scholars study social capital because of its direct effect on firms. Lin et al. [28] defined social capital as an investment in social relations with expected returns, whereas Burt [29] referred to the advantage created by a person's position in a relationship structure as social capital. According to this theory, the research on online social networks examines the formation and maintenance of online networks that support existing and new relationships [12,30-33]. Social capital generated through interactions is important for understanding what influence these interactions have on the decision-making process of the company [34-38]. According to this theory, correctly managing social networks represents an important challenge to the firm [39-42].

Stam et al. [43] showed that the social capital-performance link depends on the age of small firms, the industry, the institutional context, and the specific network or performance measures used. In addition, Carroll, Peng, and Luo, Florin et al., and Zhou et al. [7,44-46] reported that corporate social impact positively affected company performance. From the board members' perspective, Brayshay et al., Mcdonald et al., and Avina-Vazquez and Uddin [8-10] showed that social capital was important for connecting with other board members. However, Subrahmanyam [22] showed that social networks interfered with the quality of governability by satisfying social needs in the workplace. Orlitzky et al. [11] showed that the current evidence was too fractured to draw a general conclusion regarding the link between social capital and firm performance. Paniagua and Sapena [12] suggested that Twitter was a more powerful tool than Facebook to enhance business performance. Finally, scholars have argued that to gain full business value from social media, firms must develop implementation strategies based on three elements: mindful adoption, community building, and absorptive capacity [21]. 
Scholars have unanimously reported a positive relationship between social networks and internationalization. Social networks encourage increased operating profit through foreign market opportunities and internationalization [14,15]. Ellis and Pecotich, and Ellis [18,47] reported that social networks encouraged firms to start exporting, and even helped identify partners in the foreign exchange market. In addition, social networks provide knowledge about international business practices and can help improve managerial openness at the international level [16,17,48-50]. However, few studies have addressed the specific ways in which social media improves business performance.

Nowadays, the role of social media in creating social capital is relevant for fostering connection sharing and effective communication [39-41]. Several scholars have shown that the electronic media revolution is characterized by its ability to change the geographical situation of social life and not through content [51]. Moreover, the Internet has been able to narrow the gap between public and private online social networks [52-54].

\subsection{Corporate Governance (Board Size) and Social Media}

From an agency theory perspective, several studies have presented evidence of a negative correlation between board size and firm value [9,55-58]. For example, Yermack [55] used a sample of 452 large US industrial corporations to show that small boards of directors were the most effective. Eisenberg et al. [59] studied profitability for a sample of small and medium-sized Finnish firms and found a negative correlation. In contrast, Dalton et al. [60] concluded that most studies provided scant evidence of the relationship between financial performance and board structure. Based on a sample of 20,620 observations from 131 studies, a meta-analysis by Dalton et al. [61] indicated that there was a positive correlation between board size and financial performance. Several scholars have also suggested a non-significant relationship [8,62-64]. These findings led Dalton and Dalton [63] to affirm that "there is virtually no evidence related to the financial performance of the firm about either of these fundamental elements of firm's governance structures" (p. 408). Finally, Paniagua et al. [9] showed that board size was negatively related to the firm's financial performance.

Numerous studies have shown the significance of social media in data and information streams. Social media is essential for providing a new path to share information with customers [64], helping firms become familiarized with international market openings [14,15], affecting the early stages of exportation [18], recognizing international trade partners [65], providing information about worldwide business behaviors $[17,66,67]$, setting a worldwide vision and organizational scope [48,50], helping in emergencies and unexpected crises [23,68], predicting elections $[69,70]$, helping earthquake prevention [71], building marketing strategies [72-74], and predicting stock market movements $[27,75,76]$. The Internet has thereby become a key element of daily life [74].

Researchers have additionally sought to understand the use of microblogging and group structures [77-80]. Studies have also focused on the corporate use of microblogging [81-83] and the role of Twitter in marketing [84-86].

By studying the use of web-based social media in business, researchers discovered that $25 \%$ of Inc. 500 organizations used social media in their marketing strategies in 2007. One year later, that number had risen to $44 \%$ [72]. Stelzner [73] revealed that most organizations recognized the importance of social media platforms; $93 \%$ reported that they used social media in their advertising. Facebook was the biggest user (93\%), followed by Twitter (68\%), LinkedIn (56\%), Instagram (54\%), YouTube (45\%), Pinterest (30\%), and Snapchat (7\%).

Luke [87] observed that financial administrators used social media to connect with customers more regularly and over a shorter period than traditional communication practices. Luo and Chen [88] reported that guanxi-based business variables such as sales force marketing and lending had a systematic and favorable effect on a company's profitability, turnover, and domestic sales growth. Finally, Peng and Luo [5] showed that managers' interpersonal relationships with senior executives from other companies and government officials helped improve business performance in terms of market share and asset performance. 
Liu Hugo [45] pointed out that social media profiles incited exhibition by introducing a precisely arranged choice of interests, preferences, affiliations, and inclinations. According to Boyd and Ellison and Gensler et al. [39,89], this study of three social media sites distinguished endeavors to structure profiles in order to flag a specific taste ethos. Twitter is likewise helpful for product development, communication, and hiring [90]. Jung et al. [91] reported that most S\&P 1500 firms either had a corporate Twitter account or a Facebook account.

The study by Zhao and Rosson [92] selected 11 users of Twitter at a large IT organization in 2008. Heavy users may not be representative, but they can provide insight, and today's atypical customer may be tomorrow's typical customer. People use Twitter to share their life updates with their social circles. Curran [93] found that Twitter was valuable to better understand and engage with clients. In addition, Twitter can be used to study the industry and the competition by studying tweets.

Lugovic and Ahmed [94] examined the impact of Twitter on investors, drawing attention to the fact that online networking can potentially move money-related markets. They reported that three out of five financial bloggers used Twitter as their essential news source. Twitter use in the relationships of financial specialists was likewise reinforced. Similarly, Blankespoor et al. [95] showed that organizations diminished data asymmetry among investors by more comprehensively spreading their news and used Twitter to send their members links to public statements and other typical forms of exposure.

Hypothesis 1. Board members' social media presence (measured as the percentage of board members with Twitter or LinkedIn accounts) mediates the relationship between board size and operating revenue.

\subsection{Board Size and Social Media: Persuasion and Engagement}

The linkages between social media and financial performance have been studied using a broad array of empirical approaches and data. Several theories have described the advantages of social media. Paniagua and Sapena [12] showed that the number of Twitter followers was more effective than the number of Facebook likes for boosting stock prices. Trainor et al. [96] demonstrated how the use of social media positively related to relationship performance by increasing in-company capabilities that led to improved customer relationships. Corporate social networks are capable of affecting customer and supplier relationships and are relevant to building customer and human resource-related capabilities.

Social capital theory can be used to rigorously analyze the financial performance implications of social relations, human capital, and social networks. Lin et al. ([28], p. 6) defined social capital as an "investment in social relations with expected returns." Much of the literature explains that social networks are based on the transmission of knowledge or useful information through social and interpersonal links with individuals $[67,97,98]$. Adler and Kwon and Kwon and Adler $[99,100]$ reported that social networks were a central resource for companies. Belliveau et al. and Maman [36,37] indicated that social capital led to profits, arguing that the knowledge and skills that members bring to the board of directors in the form of human capital differed from the relationship links that developed with other board members.

Scholars have extensively studied the ability of social media to influence consumers' buying trends. Dahl [101] reported that three models of persuasion have been widely studied to explain what happens when an individual is faced with a sales proposition or a message originating from a brand. These models are the elaboration likelihood model (ELM), the heuristic-systematic model (HSM), and the integrated model of persuasion. Chu and Kamal [102] used the ELM to explain that blog readers were less critical of bloggers when they trusted them and paid less attention to the argument. The HSM is applied when there is little motivation to process a message and evaluation occurs based on preformed evaluation rules. Meyers-Levy and Malaviya [103] integrated elements of the ELM and the HSM to form an integrated persuasion model, highlighting a final stage of full judgment evaluation 
of information processing. Thus, individuals prefer objects and brands that are more familiar [104,105], and therefore more credible.

Friestad and Wright [106] developed a persuasion awareness model that focused on explaining the mechanisms of consumer reactions to business persuasion tactics. The persuasion awareness model is based on three factors: experience, target cognitive ability, and motivation. Friestad and Wright [107] pointed out that persuasion could affect the source in both positive and negative ways. Fogg and Tseng [108] classified credibility into four types: presumed, reputed, superficial, and experienced. In the case of Twitter, if users recognized tweets as commercial or sponsored, their credibility was likely to be lower $[109,110]$, and therefore would have lower click-through rates [111]. For social media in general, Boerman et al. [112] showed that sponsored content invited consumer distrust. Nyilasy and Reid [113] found that many practitioners recognized that awareness of persuasion was inherently negative. Similarly, companies such as Sony and Wal-Mart have been strongly criticized for releasing blogs written by paid writers to promote their products $[114,115]$.

Fogg [116] developed the functional triad of computer persuasion to persuade individuals to improve their health [117] and avoid using a telephone whilst driving [118]. Social networks enable the creation of personalized content for users, providing a tailored experience that is positively related to the user [119-121], although Bright and Daugherty [122] suggested that the perception may be less positive when receiving a personalized ad.

Thus, scholars suggest that social media offers a way for users to share success and achieve social oversight [123]. Positive support fosters learning [124], strong motivational feedback [125], and long-term participation [125].

Finally, Paniagua and Sapena [12] argued that future research should capture the effect of corporate social networks (e.g., LinkedIn) on operational performance or the effect of social marketing on sales. Therefore, we focused on the link between operating revenue and the companies' use of the social networks Twitter and LinkedIn.

Hypothesis 2. Board members' social media presence (measured as the percentage of board members with Twitter or LinkedIn accounts) moderates the relationship between board size and operating revenue.

\subsection{The Negative Effect of Social Media}

Our study remains agnostic on whether the mediating and moderating effect is positive or negative. Social media undoubtedly offer numerous opportunities, which have already been discussed. However, Baccarella et al. [126] reported a negative side of social media. They referred to this negative side of social media as the "dark side", and cited examples such as the growing interest in issues such as cyberbullying [127], online trolling [128,129], the invasion of privacy [130], fake news [131,132], firestorms [133], and the addictive nature of social media [134].

To elaborate on the theory of the dark side of social media, Baccarella et al. [126] developed a social media honeycomb framework to graphically explain the functional building blocks of social media. This framework was based on the original framework by Kietzmann et al. [135] of the building blocks of social media. Baccarella et al. [126] used this new framework to illustrate the negative side of the functionalities cited in [135]. These elements refer to the extent to which users can converse with each other, share content, let others know about their presence, form relationships, know the reputation of others, form groups, and ultimately reveal their identity. The risks of fake news and trolling stand out as potentially harmful elements for a company's reputation.

From the point of view of companies and their board members, every year, many companies, either large or small, cause an online disturbance through their actions or reactions to social media messages. Companies are subject to increasingly strict standards, and, nowadays, they are immediately punished for their mistakes. Companies might even suffer boycotts as a result of internal (comments and unfortunate actions) and external (fake news and trolling) actions, a poorly developed social media 
crisis reaction manual, or a lack of training in this field. These are just some of the factors that mean that when most of the company is unaware of social networks, social network use can have negative consequences. Finally, our approach is in line with previous research that have explored the use of technology by firms and entrepreneurs such as in [136] and also in [137] and [138].

\section{Materials and Methods}

\subsection{Data}

To test the hypotheses, we opted to use two different measures of social media activity: Twitter and LinkedIn. LinkedIn is one of the most popular social media sites designed for professional purposes. LinkedIn was officially launched on 5 May 2003, and has since become the world's largest professional network. LinkedIn has more than 546 million members from over 200 countries and territories. LinkedIn's mission is to link professionals around the world to help them become more productive and achieve their career goals. Social networking has developed from a niche activity to a widely used tool. The business and investment strategies adopted by shareholders and corporate governance differ by industry. Hawawini et al. [139] examined the effects of industry structure on business performance and found that, with the exception of a few outliers, industry characteristics were an important determinant of company performance.

Twitter is a microblogging service where users post messages with fewer than 140 characters. The average is 11 words per tweet. On 7 November 2017, this limit was doubled to 280 characters for all languages except Japanese, Korean, and Chinese. Twitter has more than 319 million monthly active users who post more than 500 million tweets per day (Twitter.com, n.d.). Kwak et al. [140] showed that the fascinating aspect of Twitter is its focus on the sharing of opinion and data, as opposed to proportional social interaction.

While the primary mission of LinkedIn is to build and maintain a network of professionals $[73,90,141]$, Twitter is used in companies for life or personal status updates, sharing information with friends or colleagues in real time, and personal Really Simple Syndication (RSS) feeds to monitor trusted external sources of news or links. Twitter is also useful for understanding and engaging with customers $[84,85,90]$. Nevertheless, Twitter users abandon the website after one month [10].

This study used a random sample of 100 companies listed on the NASDAQ. For the variables of interest, the use of Twitter by board members was measured by counting the percentage of members of the board who had a Twitter account. The use of LinkedIn by board members was measured by counting the percentage of members on the board who had a LinkedIn account. The summary statistics and control variables are shown in Table 1.

Table 1. Summary statistics (board).

\begin{tabular}{cccccc}
\hline Statistic & Definition & Mean & St. Dev. & Max & Min \\
\hline $\ln$ (Turn) & Turnover & 7.110111 & 0.7542303 & 8.683165 & 5.801892 \\
$\ln ($ Board) & Board members & 1.120985 & 0.2544584 & 1.544068 & 0 \\
LK-Board & \% Board using LinkedIn & 0.5174596 & 0.1964523 & 1 & 0 \\
TW-Board & \% Board using Twitter & 0.2040303 & 0.169137 & 0.9 & 0 \\
$\ln$ (Board) $\times$ LK-Board & Dummy & 1.085252 & 0.3175554 & 1.544068 & 0 \\
$\ln$ (Board) $\times$ T W-Board & Dummy & 0.8137615 & 0.5481564 & 1.544068 & 0 \\
Owner & Ownership dispersion & 0.836 & 0.2993326 & 1 & 0.1 \\
$\ln$ (Employees) & Number of Employees & 4.543276 & 0.8159217 & 6.361728 & 2.012837 \\
$\ln$ (Assets) & Assets & 7.215266 & 0.7146103 & 8.624377 & 5.67587 \\
$\ln$ (Capital) & Capitalization & 7.100277 & 0.7285431 & 8.497908 & 5.292236 \\
Dividend & Dividend & 0.5137506 & 0.9027808 & 7.06 & 0 \\
& $\mathrm{~N}$ & 100 & & & \\
\hline
\end{tabular}




\subsection{Structural Equation Modeling (SEM)}

We first analyzed the implications of social media (Twitter and LinkedIn) as a mediating variable in the relationship between board size. The primary statistical approach to test for mediation is hierarchical regression modeling [142]. We followed the logic and recommendations of other scholars [143,144] and used structural equation modeling (SEM) to test for mediation, as predicted by the third hypothesis.

The advantage of structural equation modeling (SEM) for testing mediation hypotheses is that all mediating conditions can be tested simultaneously and do not need to be tested in separate regression analyses [142]. The product of two paths can be tested for statistical significance [145]. Using the chi2-difference procedure, we tested the fit of the model with parameter restrictions.

The first step in testing a model of social media mediation is to build a complete correlation matrix. We analyzed two mediation models, which are reported below. Figure 1 depicts the first model, where the use of Twitter by the board is considered as a mediator of the relationship between the board and operating revenue (turnover). In a second model, we considered LinkedIn instead of Twitter as a mediator of the same relationship.

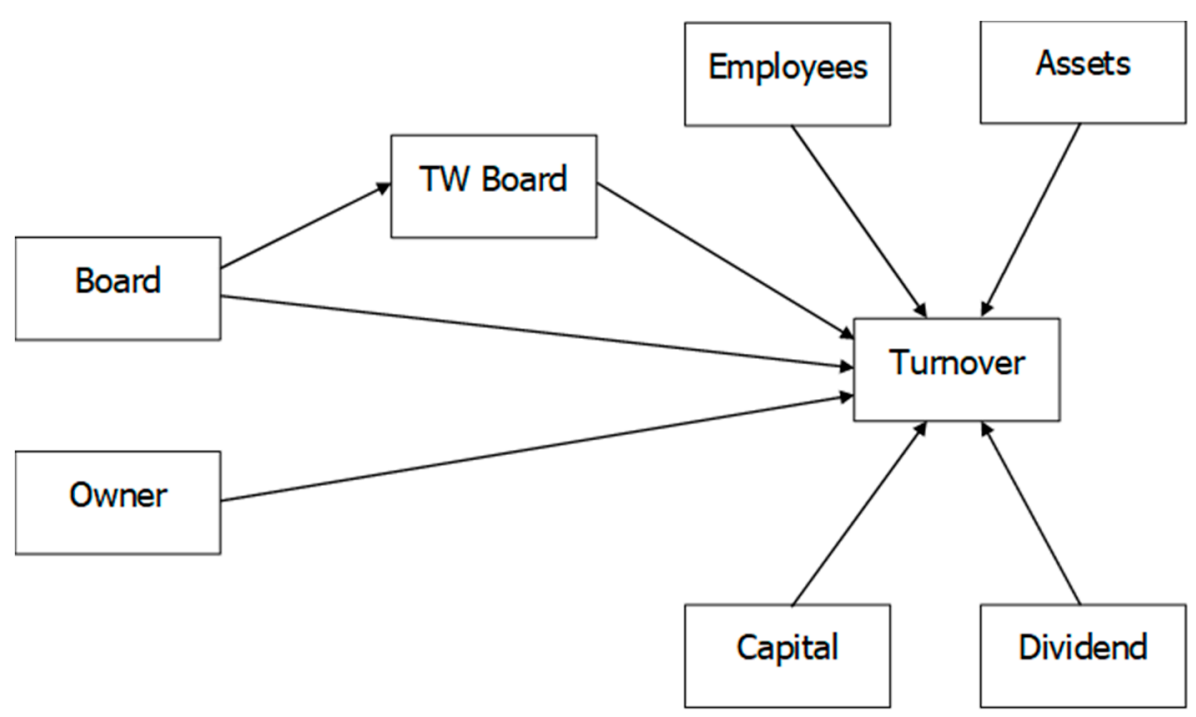

Figure 1. Mediation effects: the use of Twitter by the board.

We also analyzed the use of social media (Twitter and LinkedIn) by board members as a moderating variable. We tested the moderation model using multiple regression analysis, where all predictor variables and their interaction terms were centered prior to model estimation to improve the interpretation of the regression coefficients.

Moderator variables affect the strength and/or direction of the relationship between a predictor and an outcome, enhancing, reducing, or changing the influence of the predictor. Moderation effects are typically described as an interaction between factors or variables, where the effect of one variable depends on levels of the other variable [145].

We used the standard method for identifying a moderating effect. This entails the addition of an interaction term (the use of social media by the board) to the multiple regression model. We followed the recommendations of various scholars for analyzing and interpreting this interaction [142-145]. Two moderating models were analyzed (Twitter and LinkedIn). Figure 2 depicts the first model where the use of Twitter by the board was considered as an interaction variable that moderates the relationship between the board and operating revenue (turnover). 


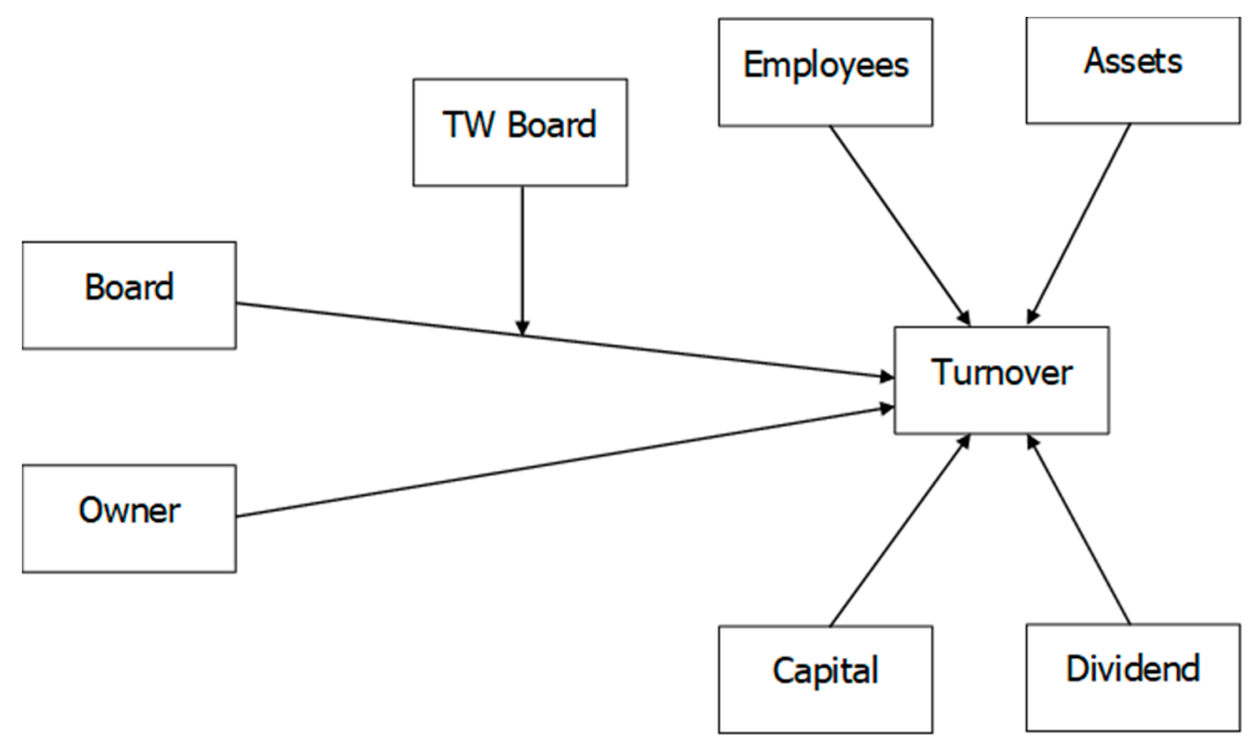

Figure 2. Moderation effects: TW-Board.

\section{Results and Discussion}

\subsection{Structural Equation Modeling (SEM)}

Tables 2 and 3 present the results of the SEM estimation to test mediation. Column 1 reports the direct effects, column 2 reports the indirect effects, and column 3 reports the total effects.

Table 2. Mediation effects: LK—Board.

\begin{tabular}{cccc}
\hline $\begin{array}{c}\text { Dependent Variable: } \\
\text { Mediation Effects: LK-Board }\end{array}$ & $\begin{array}{c}\text { (1) ln(Turnover) } \\
\text { Direct Effects }\end{array}$ & $\begin{array}{c}\text { (2) LK-Board } \\
\text { Indirect Effects }\end{array}$ & $\begin{array}{c}\text { (3) ln(Turnover) } \\
\text { Total Effects }\end{array}$ \\
\hline $\ln ($ Board) & $-0.100^{*}$ & & $-0.099^{*}$ \\
& $(0.077)$ & $0.077)$ \\
\hline Dependent variable: & $\ln$ (Turnover) & & \\
\hline LK-Board & $-0.398^{* * *}$ & $-0.398^{* * *}$ \\
& $(0.112)$ & $(0.112)$ \\
\hline $\ln$ (Board) & -0.069 & 0.040 & -0.029 \\
& $(0.093)$ & $(0.324)$ & $(0.093)$ \\
\hline Owner & $0.122^{* * *}$ & & $0.122^{* *}$ \\
& $(0.070)$ & & $(0.070)$ \\
\hline $\ln$ (Employees) & $0.357^{* * *}$ & $0.357^{* * *}$ \\
& $(0.042)$ & & $(0.042)$ \\
\hline $\ln$ (Assets) & $0.726^{* * *}$ & $0.726^{* * *}$ \\
& $(0.060)$ & & $(0.060)$ \\
\hline $\ln$ (Capital) & $-0.106^{* *}$ & $-0.106^{* *}$ \\
& $(0.058)$ & & $(0.058)$ \\
\hline Dividend & 0.015 & 0.015 \\
& $(0.023)$ & $(0.023)$ \\
\hline Observations & 100 & 100 \\
\hline
\end{tabular}

Notes: Standard error in parenthesis. ${ }^{*} p<0.10,{ }^{* *} p<0.05,{ }^{* * *} p<0.01$. 
Table 3. Mediation effects: TW-Board.

\begin{tabular}{|c|c|c|c|}
\hline $\begin{array}{c}\text { Dependent Variable: } \\
\text { Mediation Effects: TW-Board }\end{array}$ & $\begin{array}{l}\text { (1) } \ln \text { (Turnover) } \\
\text { Direct Effects }\end{array}$ & $\begin{array}{l}\text { (2) TW-Board } \\
\text { Indirect Effects }\end{array}$ & $\begin{array}{l}\text { (3) } \ln (\text { Turnover) } \\
\text { Total Effects }\end{array}$ \\
\hline $\ln$ (Board) & $\begin{array}{c}-0.106 * \\
(0.066)\end{array}$ & & $\begin{array}{l}-0.106 * \\
(0.066)\end{array}$ \\
\hline \multicolumn{4}{|l|}{ Dependent variable: $\ln$ (Turnover) } \\
\hline T W-Board & $\begin{array}{l}-0.142 \\
(0.134)\end{array}$ & & $\begin{array}{l}-0.142 \\
(0.134)\end{array}$ \\
\hline $\ln ($ Board $)$ & $\begin{array}{l}-0.090 \\
(0.099)\end{array}$ & $\begin{array}{c}0.015 \\
(0.069)\end{array}$ & $\begin{array}{l}-0.075 \\
(0.099)\end{array}$ \\
\hline Owner & $\begin{array}{l}0.123 * \\
(0.075)\end{array}$ & & $\begin{array}{l}0.123 * \\
(0.075)\end{array}$ \\
\hline $\ln$ (Employees) & $\begin{array}{l}0.391^{* * *} \\
(0.043)\end{array}$ & & $\begin{array}{l}0.391^{* * *} \\
(0.043)\end{array}$ \\
\hline $\ln$ (Assets) & $\begin{array}{l}0.713^{* * *} \\
(0.064)\end{array}$ & & $\begin{array}{l}0.713^{* * *} \\
(0.064)\end{array}$ \\
\hline $\ln$ (Capital) & $\begin{array}{l}-0.088 * \\
(0.063)\end{array}$ & & $\begin{array}{l}-0.088^{*} \\
(0.063)\end{array}$ \\
\hline Dividend & $\begin{array}{c}0.007 \\
(0.025)\end{array}$ & & $\begin{array}{c}0.007 \\
(0.025)\end{array}$ \\
\hline Observations & 100 & 100 & 100 \\
\hline
\end{tabular}

The combination of conditions failed to indicate any relationship between turnover and the number of board members who used social networks. When indirect effects were applied, the data did not support the hypothesis of mediation. Therefore, more work was needed.

To rule out that the non-significant results were driven by firm heterogeneity, meaning that small and medium enterprises (SME) have a different behavior than big firms, we divided the SEM estimation according to the quartiles of board sizes. The first quartile were firms with less than 10 board members, and the third quartile were firms with more than 18 members. Table 4 summarizes our results.

Table 4. Mediation effects by quartiles.

\begin{tabular}{lcccc}
\hline $\begin{array}{c}\text { Dependent Variable: } \\
\text { Mediation Effects: LK-Board }\end{array}$ & $\begin{array}{c}\text { (1) ln(Turnover) } \\
\text { Direct Effects }\end{array}$ & $\begin{array}{c}\text { (2) Social } \\
\text { Media-Board } \\
\text { Indirect Effects }\end{array}$ & $\begin{array}{c}\text { (3) In(Turnover) } \\
\text { Total Effects }\end{array}$ \\
\hline First Quartile & LinkedIn & -0.0402 & 0.011 & 0.052 \\
& & $(0.280)$ & $(0.127)$ & $(0.307)$ \\
\hline Third Quartile & LinkedIn & $-0.761^{*}$ & 0.001 & $-0.762^{*}$ \\
& & $(0.458)$ & $(0.045)$ & $(0.461)$ \\
\hline First Quartile & Twitter & -0.090 & 0.003 & 0.093 \\
& & $(0.306)$ & $(0.024)$ & $(0.305)$ \\
\hline Third Quartile & Twitter & $-0.768^{* *}$ & -0.013 & -0.755 \\
& & $(0.459)$ & $(0.050)$ & $(0.500)$ \\
\hline
\end{tabular}

Notes: Standard error in parenthesis. Control variables included, but not reported. ${ }^{*} p<0.10,{ }^{* *} p<0.05,{ }^{* * *} p<0.01$.

From the results reported in Table 4, we found partial empirical evidence to support hypothesis 1. Focusing on the third quartile and Twitter mediation, we observed that the direct negative effect of board size on revenue was positive and significant. However, the total effect considering the indirect effect of Twitter was not significant $(p>0.1)$. This implies that when the board size is high, the negative 
effect of increasing board members is cancelled out by social media activity on microblogging sites like Twitter. This effect was not observed when the number of board members was low (below the first quartile).

We did not observe any mediation effect for professional networking sites like LinkedIn (neither in the first nor the third quartiles). This means that our mediation hypothesis is supported for companies with large board members and general social media like Twitter.

\subsection{Moderation Effects}

We continued to study social media use by board members and enhanced the SEM analysis with an analysis of the moderating effects. Table 5 presents the results of the analysis of moderating effects. We followed a stepwise estimation procedure, adding the interaction variables sequentially. The value of R2 was high (more than $80 \%$ ), suggesting that the joint explanatory power of these variables is high.

Table 5. Moderation effects: LK-Board and TW-Board.

\begin{tabular}{|c|c|c|c|}
\hline Dependent Variable: $\ln$ (Turnover) & (1) & (2) & (3) \\
\hline $\ln ($ Board $)$ & $\begin{array}{l}-0.077 \\
(0.103)\end{array}$ & $\begin{array}{c}-0.122 * \\
(0.150)\end{array}$ & $\begin{array}{l}-0.046 \\
(0.112)\end{array}$ \\
\hline Dummy- $\ln ($ Board $) \times$ LK-Board & & $\begin{array}{l}-0.200 \\
(0.110)\end{array}$ & \\
\hline Dummy- $\ln ($ Board $) \times T W-$ Board & & & $\begin{array}{l}-0.033 \\
(0.454)\end{array}$ \\
\hline Owner & $\begin{array}{c}0.135 * * \\
(0.077)\end{array}$ & $\begin{array}{c}0.120 * * \\
(0.077)\end{array}$ & $\begin{array}{c}0.131^{* *} \\
(0.077)\end{array}$ \\
\hline $\ln ($ Employees $)$ & $\begin{array}{c}0.398^{* * *} \\
(0.045)\end{array}$ & $\begin{array}{c}0.388^{* * *} \\
(0.045)\end{array}$ & $\begin{array}{c}0.393^{* * *} \\
(0.045)\end{array}$ \\
\hline $\ln$ (Assets) & $\begin{array}{c}0.726^{* * *} \\
(0.065)\end{array}$ & $\begin{array}{c}0.712^{* * * *} \\
(0.065)\end{array}$ & $\begin{array}{c}0.715^{* * *} \\
(0.065)\end{array}$ \\
\hline $\ln$ (Capital) & $\begin{array}{c}-0.107^{* *} \\
(0.064)\end{array}$ & $\begin{array}{c}-0.094^{* *} \\
(0.063)\end{array}$ & $\begin{array}{c}-0.097 * x \\
(0.065)\end{array}$ \\
\hline Dividend & $\begin{array}{l}-0.008 \\
(0.026)\end{array}$ & $\begin{array}{l}-0.011 \\
(0.025)\end{array}$ & $\begin{array}{l}-0.007 \\
(0.026)\end{array}$ \\
\hline Observations & 100 & 100 & 100 \\
\hline $\mathrm{R} 2$ & 0.9148 & 0.9168 & 0.9144 \\
\hline
\end{tabular}

Standard errors in parentheses. ${ }^{*} p<0.10,{ }^{* *} p<0.05,{ }^{* * *} p<0.01$.

Column 1 reports the results with no interaction variables, column 2 reports the results with the interaction of the use of LinkedIn by the board, and column 3 reports the results with the interaction of the use of Twitter by the board. Overall, the results in Table 5 support hypothesis 2 for LinkedIn, which describes moderation. The results in columns 1,2, and 3 suggest that the Twitter variable had no significant moderating effect on the turnover relationship. However, when the LinkedIn variable was considered, the negative effect of board size on turnover was potentiated, in line with the dark side hypotheses of social media. If board members used LinkedIn, the negative effect of board size on revenue increased. This finding is possibly due to the fact that NASDAQ companies are high-tech entrepreneurial ventures and big startups.

By using two different estimation techniques, we found empirical evidence to support both hypotheses. However, we observed important differences between LinkedIn and Twitter. The former moderates the effect of board size (increasing its negative impact), while the latter mediates the effect of board size (cancelling its negative impact). 


\section{Conclusions, Limitations, and Future Research}

The purpose of this study was to investigate the mediating and moderating relationship of social media on the effect of board size on firm revenue. Social media is impacting the way in which all kinds of organizations, and their boards, communicate. While there is no single prescription to fit all boards for any governance issue, it is crucial for all boards to take into account the potential benefits and risks of social media.

This study examined the role of professional and general social media and, particularly, the use of LinkedIn and Twitter, on corporate governance. We studied the company's financial performance (i.e., operating revenue). The role of social media such as Twitter and LinkedIn was explored as a mediator and moderator of the relationship between the board and financial performance.

This study makes four relevant contributions to the literature on corporate governance and social media. First, our framework describes the moderating and mediating effects from the perspective of the use of social networks by board members. Second, it details the different effects of the corporate use of social networks. Our results suggest that Twitter seems to be more effective in cancelling out the negative effect of board size on revenue. Conversely, LinkedIn seems to potentiate the negative effects of the complexity of corporate governance.

Our findings are of interest for both academics and professionals. This study was based on agency theory, which provides the theoretical principles that were used to study the link between corporate governance and financial performance as well as marketing and social relationship policies for board members. The lessons learned from this study can help practitioners (e.g., CFOs, CMOs, and CEOs) design social media strategies, and establish corporate marketing and social networking guidelines for the board. The results were consistent with the initial expectations. LinkedIn was found to stand out as a complex networking-oriented social network, whereas Twitter was observed to be highly relevant for simplifying the off-line complexity of large board sizes.

This study is not without limitations. It reflects the overall situation of a heterogeneous group of companies. However, when the analysis focused on more homogeneous companies, such as those listed on the NASDAQ, the results differed. More research is needed to adapt the lessons learned from this study to specific sectors or regions and approaches. Therefore, additional studies should be conducted to explain the further relationship on financial performance.

Author Contributions: The authors contributed equally to this work.

Funding: The authors gratefully acknowledge financial support from the Generalitat Valenciana (grant: GV/2017/052) and the Research Challenges Program of Ministerio de Ciencia, Innovación y Universidades MICINN (Spanish Government \& FEDER) (grant: RTI2018-100899-B-I00 and ECO2017-83255-C3-3-P).

Conflicts of Interest: The authors declare no conflict of interest.

$\begin{array}{ll}\text { Abbreviations } \\ \text { SEM } & \text { Structural equation modeling } \\ \text { LK } & \text { LinkedIn } \\ \text { TW } & \text { Twitter } \\ \text { OLS } & \text { Ordinary least squares }\end{array}$

\section{References}

1. Felix, R.; Rauschnabel, P.A.; Hinsch, C. Elements of strategic social media marketing: A holistic framework. J. Bus. Res. 2017, 70, 118-126. [CrossRef]

2. Zhou, L.; Wu, W.; Luo, X. Internationalization and the performance of born-global SMEs: The mediating role of social networks. J. Int. Bus. Stud. 2007, 38, 673-690. [CrossRef]

3. Maury, B.; Pajuste, A. Multiple large shareholders and firm value. J. Bank. Financ. 2005, 29, $1813-1834$. [CrossRef]

4. Dey, A. Corporate Governance and Agency Conflicts. J. Acc. Res. 2008, 48, 1143-1181. [CrossRef] 
5. Bhagat, S.; Bolton, B. Corporate governance and firm performance. J. Corp. Financ. 2008, 14, $257-273$. [CrossRef]

6. Correa, M.; Garcia, J.; Úbeda, R. Análisis de la producción científica en Economía Financiera. Revista Española de Documentación Científica 2009, 32, 83-104. [CrossRef]

7. Dalton, D.R.; Dalton, C.M. Integration of Micro and Macro Studies in Governance Research: CEO Duality, Board Composition, and Financial Performance. J. Manag. 2011, 37, 404-411. [CrossRef]

8. Konijn, S.J.J.; Kräussl, R.; Lucas, A. Blockholder dispersion and firm value. J. Corp. Financ. 2011, 17, 1330-1339. [CrossRef]

9. Paniagua, J.; Rivelles, R.; Sapena, J. Corporate governance and financial performance: The role of ownership and board structure. J. Bus. Res. 2018, 89, 229-234. [CrossRef]

10. Archambault, A.; Grudin, J. A longitudinal study of facebook, linkedin, \& twitter use. In Proceedings of the SIGCHI Conference on Human Factors in Computing Systems, Austin, TX, USA, 5-10 May 2012; pp. 2741-2750.

11. Orlitzky, M.; Schmidt, F.L.; Rynes, S.L. Corporate Social and Financial Performance: A Meta-Analysis. Org. Stud. 2003, 24, 403-441. [CrossRef]

12. Paniagua, J.; Sapena, J. Business performance and social media: Love or hate? Bus. Horiz. 2014, 57, 719-728. [CrossRef]

13. Ellis, P.; Pecotich, A. Social Factors Influencing Export Initiation in Small and Medium-Sized Enterprises. J. Mark. Res. 2001, 38, 119-130. [CrossRef]

14. Reid, S. Information acquisition and export entry decisions in small firms. J. Bus. Res. 1984, 12, $141-157$. [CrossRef]

15. Gould, D.M. Immigrant Links to the Home Country: Empirical Implications for U.S. Bilateral Trade Flows. Rev. Econ. Stat. 1994, 76, 302-316. [CrossRef]

16. Haahti, A.; Madupu, V.; Yavas, U.; Babakus, E. Cooperative strategy, knowledge intensity and export performance of small and medium sized enterprises. J. World Bus. 2005, 40, 124-138. [CrossRef]

17. Eriksson, K.; Johanson, J.; Majkgard, A.; Sharma, D.D. Experiential Knowledge and Cost in the Internationalization Process. J. Int. Bus. Stud. 1997, 28, 337-360. [CrossRef]

18. Brayshay, M.; Cleary, M.; Selwood, J. Power geometries: Social networks and the 1930s multinational corporate elite. Geoforum 2006, 37, 986-998. [CrossRef]

19. Mcdonald, M.L.; Khanna, P.; Westphal, J.D. Getting Them to Think Outside the Circle: Corporate Governance, Ceos' External Advice Networks, and Firm Performance. Acad. Manag. J. 2008, 51, 453-475. [CrossRef]

20. Avina-Vazquez, C.R.; Uddin, S. Social capital, networks and interlocked independent directors: A Mexican case. J. Acc. Emerg. Econ. 2016, 6, 291-312. [CrossRef]

21. Subrahmanyam, A. Social Networks and Corporate Governance. Eur. Financ. Manag. 2008, 14, $633-662$. [CrossRef]

22. Kerkhof, P.; Schultz, F.; Utz, S. How to choose the right weapon. Social media represent both a catalyst for and weapon against brand crises. Commun. Dir. 2011, 55, 76-79.

23. Luo, X.; Wang, H.; Raithel, S.; Zheng, Q. Corporate social performance, analyst stock recommendations, and firm future returns: Research Notes and Commentaries. Strateg. Manag. J. 2015, 36, 123-136. [CrossRef]

24. Paniagua, J.; Korzynski, P.; Mas-Tur, A. Crossing borders with social media: Online social networks and FDI. Eur. Manag. J. 2017, 35, 314-326. [CrossRef]

25. Bartov, E.; Faurel, L.; Mohanram, P. Can Twitter help predict firm-level earnings and stock returns? Acc. Rev. 2018, 93, 25-57. [CrossRef]

26. Korzynski, P.; Paniagua, J.; Rodriguez-Montemayor, E. Employee creativity in a digital era: The mediating role of social media. Manag. Deciz. 2019. [CrossRef]

27. Lin, N.; Cook, K.S.; Burt, R.S. Social Capital: Theory and Research. Contemp. Sociol. 2001, 31, 28.

28. Burt, R.S. Brokerage and Closure: An Introduction to Social Capital. In Contemporary Perspectives on Organizational Social Networks; Emerald Group: Bingley, UK, 2014; pp. 161-177.

29. Wasserman, S.; Faust, K. Social Network Analysis: Methods and Applications; Cambridge University Press: Cambridge, UK, 1994; pp. 145-149.

30. Garton, L.; Haythornthwaite, C.; Wellman, B. Studying Online Social Networks. J. Comp. Mediat. Commun. 2006, 3. [CrossRef] 
31. JBeshears, o.; Choi, J.J.; Laibson, D.; Madrian, B.C. How are preferences revealed? J. Public Econ. 2008, 92, 1787-1794. [CrossRef]

32. Trainor, K.J. Relating Social Media Technologies to Performance: A Capabilities-Based Perspective. J. Pers. Sell. Sales. Manag. 2012, 32, 317-331. [CrossRef]

33. Granovetter, M. Economic Action and Social Structure: The Problem of Embeddedness. Am. J. Soc. 1985, 91, 481-510. [CrossRef]

34. Burt, R. The Social Structure of Competition. In Networks and Organizations: Structure, Form, and Action; Nohria, N., Eccles, R., Eds.; Harvard Business School Press: Boston, MA, USA, 1992; pp. 57-91.

35. Belliveau, M.A.; O’Reilly, C.A.; Wade, J.B. Social Capital at the Top: Effects of Social Similarity and Status on CEO Compensation. Acad. Manag. J. 1996, 39, 1568-1593.

36. Maman, D. The Organizational Connection: Social Capital and the Career Expansion of Directors of Business Groups in Israel. Soc. Sci. Res. 2001, 30, 578-605. [CrossRef]

37. Stevenson, W.B.; Radin, R.F. Social Capital and Social Influence on the Board of Directors. J. Manag. Stud. 2009, 46, 16-44. [CrossRef]

38. Boyd, D.; Ellison, N. Social Network Sites: Definition, History, and Scholarship. J. Comp. Mediat. Commun. 2007, 13, 210-230. [CrossRef]

39. Donath, J. Signals in Social Supernets. J. Comp. Mediat. Commun. 2007, 13, 231-251. [CrossRef]

40. Steinfield, C.; Ellison, N.B.; Lampe, C. Social capital, selfesteem, and use of online social network sites: A longitudinal analysis. J. Appl. Dev. Psychol. 2008, 29, 434-445. [CrossRef]

41. Ellison, N.B.; Boyd, D.M. Sociality Through Social Network Sites; Oxford University Press: London, UK, 2013.

42. Stam, W.; Arzlanian, S.; Elfring, T. Social capital of entrepreneurs and small firm performance: A meta-analysis of contextual and methodological moderators. J. Bus. Ventur. 2014, 29, 152-173. [CrossRef]

43. Carroll, A.B. A Commentary and an Overview of Key Questions on Corporate Social Performance Measurement. Bus. Soc. 2000, 39, 466-478. [CrossRef]

44. Peng, M.W.; Luo, Y. Managerial Ties and Firm Performance in a Transition Economy: The Nature of a Micro-Macro Link. Acad. Manag. J. 2000, 43, 486-501.

45. Florin, J.; Lubatkin, M.; Schulze, W. A Social Capital Model of HighGrowth Ventures. Acad. Manag. J. 2003, 46, 374-384.

46. Ellis, P.D. Social ties and international entrepreneurship: Opportunities and constraints affecting firm internationalization. J. Int. Bus. Stud. 2011, 42, 99-127. [CrossRef]

47. Chen, T.-J. Network Resources for Internationalization: The Case of Taiwan's Electronics Firms*. J. Manag. Stud. 2003, 40, 1107-1130. [CrossRef]

48. Sharma, D.D.; Blomstermo, A. The internationalization process of Born Globals: A network view. Int. Bus. Rev. 2003, 12, 739-753. [CrossRef]

49. Yeoh, P.-L. International learning: Antecedents and performance implications among newly internationalizing companies in an exporting context. Int. Mark. Rev. 2004, 21, 511-535. [CrossRef]

50. Meyrowitz, J. No Sense of Place: The Impact of Electronic Media on Social Behavior. Contemp. Sociol. 1986, 17,820 .

51. Donath, J.; Boyd, D. Public Displays of Connection. BT Technol. J. 2004, 22, 71-82. [CrossRef]

52. Barnes, S.B. A privacy paradox: Social networking in the United States. First Monday 2006, 11. [CrossRef]

53. Boyd, D.; Heer, J. Profiles as Conversation: Networked Identity Performance on Friendster. In Proceedings of the 39th Annual Hawaii International Conference on System Sciences, Kauai, HI, USA, 4-7 January 2006.

54. Yermack, D. Higher market valuation of companies with a small board of directors. J. Financ. Econ. 1996, 40, 185-211. [CrossRef]

55. Eisenberg, T.; Sundgren, S.; Wells, M.T. Larger board size and decreasing firm value in small firms. J. Financ. Econ. 1998, 48, 35-54. [CrossRef]

56. Dalton, D.R.; Daily, C.M.; Ellstrand, A.E.; Johnson, J.L. Meta-analytic reviews of board composition, leadership structure, and financial performance. Strateg. Manag. J. 1998, 19, 269-290. [CrossRef]

57. Dalton, D.R.; Daily, C.M.; Johnson, J.L.; Ellstrand, A.E. Number of Directors and Financial Performance: A Meta-Analysis. Acad. Manag. J. 1999, 42, 674-686.

58. Hermalin, B.E.; Weisbach, M.S. The Effects of Board Composition and Direct Incentives on Firm Performance. Financ. Manag. 1991, 20, 101-112. [CrossRef] 
59. Fogel, E.M.; Geier, A.M. Strangers in the House: Rethinking Sarbanes- Oxley and the Independent Board of Directors. Del. J. Corp. Law 2007, 32, 28-43.

60. Barnes, N.G. The Fortune 500 and Social Media: A Longitudinal Study of Blogging, Twitter, and Facebook Usage by America's Largest Companies. Available online: https://virtualmarketingofficer.com/wp-content/ uploads/2010/02/Fortune-500-and-Social-Media.pdf (accessed on 6 March 2011).

61. Ellis, K.; Michaely, R.; O'Hara, M. The Accuracy of Trade Classification Rules: Evidence from Nasdaq. J. Financ. Quant. Anal. 2000, 35, 529. [CrossRef]

62. Shleifer, A.; Vishny, R.W. A Survey of Corporate Governance. J. Financ. 1997, 52, 737-783. [CrossRef]

63. Mitchell, J.C. (Ed.) Social Networks in Urban Situations: Analyses of Personal Relationships in Central African Towns; Manchester University Press: Manchester, UK, 1969; Volume 5, p. 720.

64. Taylor, M.; Kent, M.L. Taxonomy of mediated crisis responses. Publ. Relat. Rev. 2007, 33, 140-146. [CrossRef]

65. Tumasjan, A.; Sprenger, T.O.; Sandner, P.G.; Welpe, I.M. Predicting elections with twitter: What 140 characters reveal about political sentiment. ICWSM 2010, 10, 178-185.

66. Stolee, G.; Caton, S. Twitter, Trump, and the Base: A Shift to a New Form of Presidential Talk? Sign. Soc. 2018, 6, 147-165. [CrossRef]

67. Sakaki, T.; Okazaki, M.; Matsuo, Y. Earthquake Shakes Twitter Users: Real-time Event Detection by Social Sensors. In Proceedings of the 19th International Conference on World Wide Web, Raleigh, NC, USA, 26-30 April 2010; pp. 851-860.

68. Fisher, T. ROI in social media: A look at the arguments. J. Database Market. Custom. Strat. Manag. 2009, 16, 189-195. [CrossRef]

69. Stelzner, M. 2017 Social Media Marketing Industry Report; Technical Report; Social Media Examiner: Poway, CA, USA, 2017.

70. Bollen, J.; Mao, H.; Zeng, X. Twitter mood predicts the stock market. J. Computat. Sci. 2011, 2, 1-8. [CrossRef]

71. Amichai-Hamburger, Y.; Vinitzky, G. Social network use and personality. Comput. Hum. Behav. 2010, 26, 1289-1295. [CrossRef]

72. Java, A.; Song, X.; Finin, T.; Tseng, B. Why We Twitter: Understanding Microblogging Usage and Communities. In Proceedings of the 9th WebKDD and 1st SNA-KDD 2007 Workshop on Web Mining and Social Network Analysis, San Jose, CA, USA, 12-15 August 2007; pp. 56-65.

73. Huberman, B.A.; Romero, D.M.; Wu, F. Social networks that matter: Twitter under the microscope. First Monday 2008, 14. [CrossRef]

74. Honey, C.; Herring, S.C. Beyond Microblogging: Conversation and Collaboration via Twitter. In Proceedings of the 42nd Hawaii International Conference on System Sciences, Waikoloa, HI, USA, 5-8 January 2009; pp. $1-10$.

75. Luo, T.; Gao, F. Enhancing Classroom Learning Experience by Providing Structures to Microblogging-Based Activities. J. Inf. Technol. Educ. Innov. Pract. 2012, 11, 199-211. [CrossRef]

76. Wandke, H.; Kain, S.; Struve, D. Mensch E Computer 2009: Grenzenlos Frei!? Oldenbourg Verlag: Munchen, Germany, 2009.

77. Riemer, K.; Richter, A. Tweet Inside: Microblogging in a Corporate Context. In Proceedings of the Bled eConference, Bled, Slovenia, 20-23 June 2010; p. 41.

78. Rezaeenour, J.; Niknam, M. Enterprise microblogging tool to increase employee participation in organizational knowledge management. Adv. Comp. Sci. Int. J. 2013, 2, 44-47.

79. Culnan, M.; McHugh, P.; Zubillaga, J. How large US companies can use Twitter and other social media to gain business value. MIS Quart. Execut. 2010, 9, 243-259.

80. Jansen, B.; Zhang, M.; Sobel, K.; Chowdury, A. Twitter power: Tweets as electronic word of mouth. J. Am. Soc. Inf. Sci. Technol. 2009, 60, 2169-2188. [CrossRef]

81. Varadharajan, S. Web-Based Multimedia Advancements in Data Communications and Networking Technologies. Int. J. Bus. Data Commun. Netw. 2012, 9, 1-10.

82. Witkemper, C.; Lim, C.H.; Waldburger, A. Social media and sports marketing: Examining the motivations and constraints of Twitter users. Sport Mark. Quart. 2012, 21, 170.

83. Luke, K. Marketing the New-fashioned Way: Connect with your target market through social networking sites. J. Financ. Plan. 2009, 18, 18-19.

84. Luo, Y.; Chen, M. Does Guanxi Influence Firm Performance? Asia Pac. J. Manag. 1997, 14, 1-16. [CrossRef] 
85. Gensler, S.; Völckner, F.; Liu-Thompkins, Y.; Wiertz, C. Managing Brands in the Social Media Environment. J. Interact. Mark. 2013, 27, 242-256. [CrossRef]

86. Mihalcea, A.D.; Savulescu, R.M. Social networking sites: Guidelines for creating new business opportunities through Facebook, Twitter and Linkedin. Manag. Dynam. Knowledg. Econ. 2013, 45, 303-315.

87. Jung, M.J.; Naughton, J.P.; Tahoun, A.; Wang, C. Do Firms Strategically Disseminate? Evid. Corp. Use Soc. Media 2017, 93, 225-252.

88. Zhao, D.; Rosson, M.B. How and Why People Twitter: The Role That Micro-blogging Plays in Informal Communication at Work. In Proceedings of the ACM 2009 International Conference on Supporting Group Work, Sanibel Island, FL, USA, 10-13 May 2009; pp. 243-252.

89. Curran, J. Media and Power; Routledge: New York, NY, USA, 2012.

90. Lugovic, S.; Ahmed, W. An Analysis of Twitter Usage Among Startups in Europe. In Proceedings of the 5th International Conference the Future of Information Sciences (INFuture), Zagreb, Croatia, 11-13 November 2015; pp. 299-308.

91. Blankespoor, E.; Miller, G.S.; White, H.D. The Role of Dissemination in Market Liquidity: Evidence from Firms' Use of TwitterTM. Acc. Rev. 2013, 89, 79-112. [CrossRef]

92. Trainor, K.J.; Andzulis, J.; Rapp, A.; Agnihotri, R. Social media technology usage and customer relationship performance: A capabilities-based examination of social CRM. J. Bus. Res. 2014, 67, 1201-1208. [CrossRef]

93. Rogers, E.; Kincaid, D. Communication networks: Toward a new paradigm for research. Contemp. Sociol. 1981, 84, 986-988.

94. Weimann, G. The Influentials: Back to the Concept of Opinion Leaders? Publ. Opin. Quart. 1991, 55, 267. [CrossRef]

95. Adler, P.S.; Kwon, S.-W. Social Capital: Prospects for a New Concept. Acad. Manag. Rev. 2002, $27,17-40$. [CrossRef]

96. Kwon, S.-W.; Adler, P.S. Social Capital: Maturation of a Field of Research. Acad. Manag. Rev. 2014, 39, 412-422. [CrossRef]

97. Dahl, S. Social Media Marketing: Theories and Applications; SAGE Publications Ltd.: Thousand Oaks, CA, USA, 2018.

98. Chu, S.C.; Kamal, S. The Effect of Perceived Blogger Credibility and Argument Quality on Message Elaboration and Brand Attitudes. J. Interact. Advert. 2008, 8, 26-37. [CrossRef]

99. Meyers-Levy, J.; Malaviya, P. Consumers' Processing of Persuasive Advertisements: An Integrative Framework of Persuasion Theories. J. Mark. 1999, 63, 45-60.

100. Zajonc, R.B. Attitudinal effects of mere exposure. J. Person. Soc. Psychol. 1968, 9, 1-27. [CrossRef]

101. Zajonc, R.B. Mere exposure: A gateway to the subliminal. Curr. Direct. Psychol. Sci. 2001, 10, $224-228$. [CrossRef]

102. Friestad, M.; Wright, P. The Persuasion Knowledge Model: How People Cope with Persuasion Attempts. J. Consum. Res. 1994, 21, 1-31. [CrossRef]

103. Fogg, B.J.; Tseng, H. The Elements of Computer Credibility. In Proceedings of the SIGCHI Conference on Human Factors in Computing Systems, Pittsburgh, PN, USA, 15-20 May 1999; pp. 80-87.

104. Heine, C. 'McRib Is Back' Promotion Turns into a Twitter Roast. Available online: https://www.clickz.com/ mcrib-is-back-promotion-turnsinto-a-twitter-roast/53928/ (accessed on 2 November 2010).

105. Sherwin, A. \#ad: Tweeting Celebrities Warned to Reveal Commercial Interests Following Coronation Street Dispatches Sting. The Independent. 2013. Available online: https:/www.independent.co.uk/news/people/news/ ad-tweetingcelebrities-warned-to-reveal-commercial-interests-following-coronation-streetdispatches-8690864. html. (accessed on 5 July 2013).

106. Yoo, C.Y. The Effects of Persuasion Knowledge on Click-Through of Keyword Search Ads: Moderating Role of Search Task and Perceived Fairness. Journal. Mass. Commun. Quart. 2009, 86, 401-418. [CrossRef]

107. Boerman, S.C.; Willemsen, L.M.; van der Aa, E.P. “This Post Is Sponsored”. J. Interact. Mark. 2017, 38, 82-92. [CrossRef]

108. Nyilasy, G.; Reid, L.N. Agency Practitioner Theories of How Advertising Works. J. Advert. 2009, 38, 81-96. [CrossRef]

109. Gogoi, P. Wal-Mart vs. the Blogosphere. Available online: https://www.bloomberg.com/news/articles/200610-17/wal-mart-vs-dot-the-blogospherebusinessweek-business-news-stock-market-and-financial-advice (accessed on 17 October 2006). 
110. Megagames News. Sony Fake PSP Blog Busted. Available online: https://megagames.com/news/sony-fakepsp-blog-busted (accessed on 14 December 2006).

111. Fogg, B.J. Persuasive technologies. Commun. ACM 1999, 42, 27-29. [CrossRef]

112. Torning, K.; Oinas-Kukkonen, H. Persuasive system design: State of the art and future directions. In Proceedings of the 4th International Conference on Persuasive Technology, Claremont, CA, USA, 26-29 April 2009; p. 30.

113. Miranda, B.; Jere, C.; Alharbi, O.; Lakshmi, S.; Khouja, Y.; Chatterjee, S. Examining the efficacy of a persuasive technology package in reducing texting and driving behavior. In Proceedings of the International Conference on Persuasive Technology, Sydney, NSW, Australia, 3-5 April 2013; pp. 137-148.

114. Chandran, S.; Morwitz, V.G. Effects of Participative Pricing on Consumers' Cognitions and Actions: A Goal Theoretic Perspective. J. Consum. Res. 2005, 32, 249-259. [CrossRef]

115. Noar, S.M.; Benac, C.N.; Harris, M.S. Does tailoring matter? Metaanalytic review of tailored print health behavior change interventions. Psychol. Bull. 2007, 133, 673-693. [CrossRef] [PubMed]

116. Sundar, S.S.; Marathe, S.S. Personalization versus Customization: The Importance of Agency, Privacy, and Power Usage. Hum. Commun. Res. 2010, 36, 298-322. [CrossRef]

117. Bright, L.F.; Daugherty, T. Does customization impact advertising effectiveness? An exploratory study of consumer perceptions of advertising in customized online environments. J. Mark. Commun. 2012, 18, $19-37$. [CrossRef]

118. Hogan, B.E.; Linden, W.; Najarian, B. Social support interventions. Clinic. Psychol. Rev. 2002, 22, $381-440$. [CrossRef]

119. Skinner, B.F. The Behavior of Organisms: An Experimental Analysis; AppletonCentury: New York, NY, USA, 1938.

120. Sluis-Thiescheffer, R.J.W.; Bekker, M.M.; Eggen, J.H.; Vermeeren, A.P.O.S.; de Ridder, H. Development and application of a framework for comparing early design methods for young children. Interact. Comput. 2011, 23, 70-84. [CrossRef]

121. Schubart, J.R.; Stuckey, H.L.; Ganeshamoorthy, A.; Sciamanna, C.N. Chronic Health Conditions and Internet Behavioral Interventions: A Review of Factors to Enhance User Engagement. Comput. Inf. Nurs. 2011, 29, 81-92. [CrossRef] [PubMed]

122. Baccarella, C.V.; Wagner, T.F.; Kietzmann, J.; McCarthy, I.P. Social media? It's serious! Understanding the dark side of social media. Eur. Manag. J. 2018, 36, 431-438. [CrossRef]

123. Keeffe, G.S.O.; Clarke-Pearson, K. Clinical report the impact of social media on children, adolescents, and families. Pediatrics 2011, 127, 800-804. [CrossRef]

124. Hardaker, C. Trolling in asynchronous computer-mediated communication: From user discussions to academic definitions. J. Polteness Res. Lang. Behav. Cult. 2010, 6, 215-242. [CrossRef]

125. Buckels, E.E.; Trapnell, P.D.; Paulhus, D.L. Trolls just want to have fun. Personality and Individual Differences 2014, 67, 97-102. [CrossRef]

126. Pai, P.; Arnott, D.C. User adoption of social networking sites: Eliciting uses and gratifications through a means-end approach. Comput. Hum. Behav. 2013, 29, 1039-1053. [CrossRef]

127. Allcott, H.; Gentzkow, M. Social Media and Fake News in the 2016 Election. J. Econ. Persp. 2017, 31, $211-236$. [CrossRef]

128. European Commission. Final Report of the High Level Expert Group on Fake News and Online Disinformation; European Commission: Brussels, Belgium, 2018.

129. Pfeffer, J.; Zorbach, T.; Carley, K.M. Understanding online firestorms: Negative word-of-mouth dynamics in social media networks. J. Mark. Commun. 2014, 20, 117-128. [CrossRef]

130. Blackwell, D.; Leaman, C.; Tramposch, R.; Osborne, C.; Liss, M. Extraversion, neuroticism, attachment style and fear of missing out as predictors of social media use and addiction. Person. Individ. Dif. 2017, 116, 69-72. [CrossRef]

131. Kietzmann, J.H.; Hermkens, K.; McCarthy, I.P.; Silvestre, B.S. Social media? Get serious! Understanding the functional building blocks of social media. Bus. Horiz. 2011, 54, 241-251. [CrossRef]

132. Eggers, F.; Hatak, I.; Kraus, S.; Niemand, T. Technologies that support marketing and market development in SMEs-Evidence from social networks. J. Small Bus. Manag. 2017, 55, 270-302. [CrossRef]

133. Kraus, S.; Roig-Tierno, N.; Bouncken, R.B. Digital innovation and venturing: An introduction into the digitalization of entrepreneurship. Rev. Manag. Sci. 2019, 13, 519-528. [CrossRef] 
134. Ferreira, J.J.; Fernandes, C.I.; Kraus, S. Entrepreneurship research: Mapping intellectual structures and research trends. Rev. Manag. Sci. 2019, 13, 181-205. [CrossRef]

135. Hawawini, G.; Subramanian, V.; Verdin, P. Is performance driven by industry-or firm-specific factors? A new look at the evidence. Strateg. Manag. J. 2003, 24, 1-16. [CrossRef]

136. Kwak, H.; Lee, C.; Park, H.; Moon, S. What is Twitter, a Social Network or a News Media? In Proceedings of the 19th International Conference on World Wide Web, Raleigh, NC, USA, 26-30 April 2010; pp. 591-600.

137. Edosomwan, S.; Prakasan, S.K.; Kouame, D.; Watson, J.; Seymour, T. The history of social media and its impact on business. J. Appl. Manag. Enterp. 2011, 16, 79.

138. Baron, R.M.; Kenny, D.A. The moderator-mediator variable distinction in social psychological research: Conceptual, strategic, and statistical considerations. J. Person. Soc. Psychol. 1986, 51, 1173-1182. [CrossRef]

139. James, L.R.; Mulaik, S.A.; Brett, J.M. A Tale of Two Methods. Org. Res. Method. 2006, 9, 233-244. [CrossRef]

140. MacKinnon, D.P.; Lockwood, C.M.; Hoffman, J.M.; West, S.G.; Sheets, V. A comparison of methods to test mediation and other intervening variable effects. Psychol. Method. 2002, 7, 83-104. [CrossRef]

141. Fairchild, A.J.; MacKinnon, D.P.A. General Model for Testing Mediation and Moderation Effects. Prev. Sci. 2009, 10, 87-99. [CrossRef] [PubMed]

142. McClelland, G.H.; Judd, C.M. Statistical difficulties of detecting interactions and moderator effects. Psychol. Bull. 1993, 114, 376. [CrossRef] [PubMed]

143. Jaccard, J.; Turrisi, R. Interaction Effects in Multiple Regression; SAGE: Thousand Oaks, CA, USA, 2003.

144. Aguinis, H. Regression Analysis for Categorical Moderators; Guilford Press: New York, NY, USA, 2004.

145. Judd, C.M.; Kenny, D.A.; McClelland, G.H. Estimating and testing mediation and moderation in within-subject designs. Psychol. Method. 2001, 6, 115. [CrossRef]

(C) 2019 by the authors. Licensee MDPI, Basel, Switzerland. This article is an open access article distributed under the terms and conditions of the Creative Commons Attribution (CC BY) license (http://creativecommons.org/licenses/by/4.0/). 